\title{
An Overview of Medical Malpractice Law in the United States Including Legislative and the Health Care Industry's Responses to Increased Claims
}

\author{
THOMAS ALLAN HELLER
}

\begin{abstract}
Medical Malpractice claims are frequently asserted in the United States. At various time and places, an extraordinarily high number of claims and payouts led to what some have called medical malpractice crises. Consequently, in some geographical locations physicians either could not purchase malpractice insurance as carriers withdrew from the market, or, insurance became increasingly expensive and the overall costs associated with the delivery of health care continued to rise. Other undesirable consequences of these crises included a shortage of qualified physicians in certain parts of the country. Many of the states responded to these problems legislatively through a long series of tort reform measures. The health care industry itself has evolved in numerous ways. In particular, many health care providers have turned away from traditional private insurance models to self-insured models such as captives. Further, the industry has continued to consolidate, with fewer, but larger hospitals and clinics, and with an increasing number of physicians employed directly by hospitals and large clinics. The results of all of these changes have had mixed results.
\end{abstract}

Keywords: $\bullet$ medical malpractice $・$ defensive medicine $\bullet$ medical malpractice crises $\bullet$ tort reform $\bullet$ consolidation of health care industry - group captives

CORRESPONDENCE AdDRESs: Thomas Allan Heller, Visiting Guest Expert, University of Maribor, Faculty of Law, Mladinska ulica 9, 2000 Maribor, Slovenia, e-mail: heller6651@msn.com. 

Increased Claims

\section{The Function of Tort Law and the Concept of Negligence.}

The law of torts in the United States serves several important functions. First, it is meant to help deter and prevent accidents. In theory, this is due to the fact the wrongdoer, known as the "tortfeasor," can be held financially responsible (i.e. liable) for his or her accident causing behavior. In this sense, tort law is a form of social control as it is designed to promote good social conduct. That is, the threat of financial liability encourages safe behavior. Second, and as a corollary to the first factor, it provides compensation to accident victims and their families, as the injured parties have legal recourse against the tortfeasor and the tortfeasor's insurers (assuming the tortfeasor is insured for the injury-causing conduct) (Prosser et al., 1984).

On the other hand, tort law, as is the case with other substantive areas of the law, is concerned with fairness to all parties. Society will not long respect the legal system if it does not perceive it as fundamentally fair to everyone. In that respect, a counterbalance to the idea of tort law protecting "victims" of wrongful conduct is the notion that tort (and other) laws should not unduly burden productive activities. To some extent, the existence of liability insurance as something persons and entities can purchase to insure them in the event of liability-causing activities can help minimize, if not totally eliminate, catastrophic risk to the tortfeasor. Additionally, a fair and just legal system requires an efficient and effective legal process, that is, one that has standards that are understandable, and which therefore provide clear guidance to the bench and bar, and more widely, to the public. A legal system that provides reasonably speedy resolutions to legal disputes, and which is reasonably affordable to all, also promotes the public's confidence in the system.

One major sub-area of the law of torts is the law of negligence, which in its most basic sense provides that everyone has an obligation (known in the law as a "duty") to perform their actions with "ordinary" or "reasonable" care. In tort parlance, persons have to carry out their activities as would the so-called "reasonably prudent person." In effect, this requires a sliding scale of prudence of care, in the sense that the degree of care required is commensurate with the foreseeable risk of harm involved in the activity being carried out. Logically, the greater the risk of harm is in the act being carried out, the greater the care that must be taken. By way of example, working with explosives would require maximum care and preventative measures while the mere act of walking around town would be correspondingly less. The general idea is that if a risk of harm is reasonably foreseeable (to the hypothetical reasonably prudent person), and the actor's actual conduct falls below the standard of reasonable care and injury or damage results, the actor can be held liable ("in tort") for all damages that proximately follow from the actor's negligence. 
T. Allan Heller: An Overview of Medical Malpractice Law in the United States Including Legislative and the Health Care Industry's Responses to Increased

Claims

\section{Introduction to Medical Malpractice Law in the United States}

In present day, the average person seeks medical care many times over a life time, starting often before birth (as fetus in womb), and most typically from a host of providers, and in various settings, including medical clinics, hospitals and similar facilities. As of 2015, a typical person in the United States visited the doctor an average of 4 times per year (https://www.statista.com/statistics/236589/number-ofdoctor-visits-per-capita-by-country/). The 2014 data from the Federation of State Medical Boards shows that as of that time there were over 916,000 licensed physicians in the United States (Young et al., 2014). According to statistics from the American Hospital Association, in 2017 there were over 5,500 registered hospitals in the United States; nearly 5,000 more community hospitals; nearly 3,000 nongovernmental not-for-profit community hospitals; over 1,000 investor-owned (for-profit) community hospitals; nearly 1,000 state and local government community hospitals; and, hundreds of other government hospitals, psychiatric hospitals, nonfederal long term care hospitals and prison and college (i.e., other) hospitals (American Hospital Association, 2016).

Given the number of encounters the average person has with medical professionals, and the extant numbers of physicians and hospitals, it should therefore come as no surprise that medical negligence does occur with some degree of regularity, and that the court system is called upon to adjudicate many of those claims. Claims for negligence against physicians, hospitals and other health care providers are one subcomponent of tort (negligence) law, and such claims are referred to generally as claims for medical malpractice. As with other legal claims, the vast majority are resolved without the need for formal legal action (i.e., a lawsuit). However, when not resolved short of a lawsuit, medical malpractice claims are generally brought in state court (some are filed in the federal court system). Given the autonomy of the states to conduct their own affairs, the laws regarding medical negligence vary from state to state. A comprehensive discussion of the differences in state laws is beyond the scope of this paper.

Generally speaking, however, under well-accepted principles of tort law, in order to prevail in a medical malpractice suit, the plaintiff ordinarily must establish each of the following legal elements: (1) the person or entity being sued owed plaintiff a legal duty; (2) there was a breach of that duty; (3) that breach proximately caused the plaintiff harm; and (4) the plaintiff sustained damages (Bal, 2009; Prosser et al., 1984).

Concerning the duty element, the plaintiff must first establish that a "physicianpatient" relationship existed (Kraljić, 2017; Unver, 2016). This element is usually met rather easily. Assuming such a relationship, then the physician (and/or health 
care facility) owes the plaintiff a duty to exercise reasonable care in providing the treatment.

The extent and scope of the duty owed relates to the so-called standard of care the physician/health care facility is required to follow. The standard of care has expanded over the years from a local to a national standard. The plaintiff must establish, almost always through expert testimony, what the standard is and that the care provided fell below that standard. As a general proposition, medical malpractice is defined as any act or omission by a physician during treatment of a patient that deviates from accepted norms of practice in the medical community. What exactly those accepted norms of practice are form issues at the crux of most contested medical malpractice cases. ${ }^{1}$

Thirdly, the plaintiff must establish, again nearly always through the use of expert testimony, that the sub-standard care provided actually caused, in a direct sequence (i.e., proximately caused), the complained of injury. That is, if the physician or health care facility was negligent in some way, but that negligent act did not actually (proximately) cause the injury complained of, then the physician or health care facility will not be held liable to the plaintiff.

Lastly, the plaintiff must establish damages. The fact of some sort of damage is usually (though not always) easy to prove. What typically is disputed, in one or more ways, is the nature and extent of plaintiffs' damages, issues we turn to next in this paper.

\section{Explanation and Types of Damages}

The types of damages that might be awardable to a plaintiff in a medical malpractice case are similar to those available to plaintiffs in other personal injury cases. However, since the landscape in medical malpractice cases (discussed later in this paper) has focused largely on issues stemming from damages (and large damages awards), the types of damages are first discussed.

\subsection{Economic Damages}

The first broad category of available damages is known as economic damages. As this name implies, included are past and future medical bills; past and future loss of income, including loss of future earning capacity; past and future loss of services; damages stemming from the need for a future health care plan post-accident; past and future "other" out-of-pocket expenses (such as transportation costs to/from medical or other appointments), among possible other economic losses. Economic damages are subject to calculation, but often are the subject of disputed lay and expert testimony, sometimes from numerous disciplines such as medical doctors, 
T. Allan Heller: An Overview of Medical Malpractice Law in the United States Including Legislative and the Health Care Industry's Responses to Increased

economists, nurses, care planners, vocational rehabilitation specialists, among others.

\subsection{General/Non-Economic Damages}

The second broad category of damages is called "general" or "non-economic" damages. General damages include compensation for past and future pain and suffering; disfigurement; humiliation; aggravation; anxiety; fear of future injury; loss of companionship; etc. General damages are highly subjective in nature and are not readily subject to calculation.

In a jury case, and assuming the plaintiff otherwise establishes the elements to prove liability, the jury is given a special verdict form with which to calculate damages, with each of the above-mentioned categories of damages listed. The jury is free, based on the evidence, to award damages for any or all of these specific categories, by placing a dollar amount on the blank line next to each such category. Punitive damages are allowed in some states for essentially malicious or willful conduct.

\section{The Medical Malpractice Crises and Where the Goals of Tort Law Clash}

With this legal framework behind us, we can now move on to the core of this paper, which is, how have the various "stakeholders" involved in the medical malpractice arena (injured persons, physicians, medical clinics, insurers, the legal system, the broader public, the legislative system) in the United States responded when the multiple goals of the tort system, discussed at the very outset of this paper, have found themselves on a collision course. That is to say, what has occurred when there has been excessive strain placed on the medical profession (and their insurers) due to large volumes of medical malpractice claims and monetary payouts (settlements and judgments)? As mentioned earlier, tort law has principal aims of not only reasonably compensating injury victims, and employing the threat of claims/lawsuits to help promote safe practices, but also to foster notions of fairness and predictability, and to not unduly harm and hinder useful economic activities. It is fair to conclude that these multiple goals have collided in the medical malpractice arena. The remainder of this paper will focus on an overview of the recent history of medical malpractice claims; the substantial fallout from those claims; and, how the courts, various legislative bodies, insurers, physicians and medical clinics (that is, the primary stakeholders) have responded.

There is a substantial body of literature that has shown that the number of medical malpractice claims and lawsuits has occurred in waves over the last 50 years or so. Three periods of "crisis" leading to soaring medical malpractice costs occurred in the 1970's, the mid-1980's and into the 1990's and again in the mid-2000's (Stark, 
2016). As one might expect in a country as broad, diverse and expansive as the United States, there has been considerable variability in the number of claims asserted; the amounts of settlements paid and judgments awarded; and, the costs of medical malpractice insurance from state to state and over time. According to the National Practitioner Data Bank (NPDB), total payments for physician medical malpractice claims in the United States more than doubled between 1991 and 2003, rising from $\$ 2.12$ billion in 1991 to $\$ 4.45$ billion in 2003. During that same period of time, the average payout rose from somewhere between approximately $88 \%$ to $131 \%$, or approximately $\$ 140,000$ to $\$ 290,000$ (US Dept of Health \& Human Services, 2014).

Data gathered by the NPDB and the Physicians Insurers Association of America (PIAA) show that the number of paid claims for medical malpractice increased at a fairly moderate rate of approximately $7 \%$ to $12 \%$ between the years $1991-2003$ (claims estimates of approximately 13,700 in 1991 to $15,000+$ in 2003.) The NPDB and PIAA estimate that the average defense costs per claim also roughly doubled from 1991 to 2001 (for paid claims roughly $\$ 21,000$ to $\$ 44,000$ ) (US Dept of Health $\&$ Human Services, 2014). As indicated above, the number of claims asserted, and the amount of dollars paid per claim, varies significantly across the various states. A complete comparative analysis is beyond the scope of this paper.

\section{Consequences of the Increases in Number of Claims and Payouts}

That victims of medical negligence should be fairly compensated is unquestioned. Compensating victims of negligence, or other wrongful conduct, regardless of the setting in which injury occurs, is a bedrock principle of the United States system of justice. On the other hand, and as the extensive literature has pointed out, periods of time when there have been precipitous spikes in the number of medical malpractice claims (and unexpectedly high dollar payouts) have led to numerous undesirable consequences for the multiple stakeholders (Mello et al., 2005). For example, malpractice premiums for some physicians, and in particular those practicing in certain high-risk specialty fields (such as surgery or obstetrics), and for some physicians that have practiced in geographical regions of the United States that have been particularly hard hit by claims, such as the northeast, increased dramatically. Some insurance carriers withdrew from some of these high risk markets or would not insure physicians practicing in high-risk fields. As already discussed, tort law encourages persons and entities to purchase insurance (indeed, the law often requires persons or entities to have certain levels of insurance coverage as a condition of doing business/being licensed) and an overriding theme in the law and society is that persons and entities will, more often than not, have insurance to protect victims of wrongdoing. Therefore, conditions leading to a lack of available insurance are, in general, not desirable from a public policy standpoint. 
T. Allan Heller: An Overview of Medical Malpractice Law in the United States Including Legislative and the Health Care Industry's Responses to Increased

Claims

Other undesirable consequences of the spikes in medical malpractice claims and the lack of available (or reasonably affordable) insurance are that physicians decided not to practice is some regions of the United States or to practice in lower risk fields of medicine in regions where claims were prevalent. These decisions, in turn, led to shortages of competent physicians in certain parts of the country, and a shortage of certain specialists as well. Those decisions, reasonable from the point of view of physicians, were highly detrimental to the public.

Another adverse consequence of increased medical malpractice claims is that the medical profession began to engage in what is commonly referred to as "defensive medicine," namely prescribing (too?) many tests, making (too?) numerous referrals to other physicians (specialists) and the like. Much has been written on this topic, the details of which again are beyond the scope of this paper (U.S. Congress, Office of Technology Assessment, 1994). However, from a societal standpoint, a legitimate and important concern is that this practice of (overly) defensive medicine has needlessly and unreasonably driven up the cost of health care in the United States. The country in fact continues to grapple with the escalating and often disastrous consequences of exorbitant health care (Obama care; dissatisfaction in some quarters with Obama care; efforts to replace/modify Obama care; continued collapse of insurance markets, etc.).

\section{Reasons Behind Spikes in Medical Malpractice Claims and High Costs for Medical Care}

Others have analyzed the causes of the spikes in medical malpractice claims and fallout from same (The Council for State Governments, 2003). While perhaps not a complete list, a review of some of this literature leads to the following list of some of the most common causes identified for the increase in medical malpractice claims and high payouts to the patient victims. Some say there are too many plaintiffs, personal injury attorneys and extensive litigation. Others claim some of the jury verdicts and settlements are excessively high. Yet others argue that the law wrongly permits unqualified experts to testify on behalf of plaintiffs at the trial of medical malpractice cases. Other arguments include that the substantive and procedural civil trial rules are too slanted in favor of plaintiff to the detriment of the medical profession. Still others point to a flawed medical malpractice insurance market. And, as discussed earlier in this paper, many argue that the risk of a medical negligence claim (and concomitant risk of losing insurance coverage; or maintaining coverage but paying high premiums; and, having ones professional reputation sullied) has backed physicians into a corner, forcing them to practice defensive medicine. 
T. Allan Heller: An Overview of Medical Malpractice Law in the United States Including Legislative and the Health Care Industry's Responses to Increased Claims

\section{$7 \quad$ Responses by the States - Tort Reform}

\subsection{Introduction and Overview}

As a consequence of these undesirable consequences, state legislatures around the country; physicians and health care facilities; and, the insurance industry, responded. We will first address actions taken at the state legislative level (Bal, 2009).

State legislatures have attempted to address some of the problems identified above in various ways, under the umbrella of what has been called "Tort Reform." While the judicial system in the United States has certainly faced significant challenges in dealing with various other mass tort litigation, such as the asbestos litigation, which is the longest mass tort litigation in the United States and which is still ongoing, and which also led to tort reform efforts, medical malpractice litigation has drawn particular attention when it has come to legislative efforts to reform the way the legal system works.

Tort reform in the medical negligence arena has occurred more or less continually over the last 40 years. Some states have been much more active than others, and a complete state be state discussion, or any attempt to discuss completely all of these legislative initiatives, is beyond the scope of this paper.

As might be expected in a democratic society, these reforms have largely been promoted by the health care and insurance industries, who have claimed reforms are necessary in order to help minimize the practices of defensive medicine; to encourage physicians to practice in all areas of the country and to practice in high risk areas of medicine such as surgery; to make insurance more readily available and affordable; and, in a global sense, to help drive down the overall cost of health care in the United States, making it more available to more people at a more affordable cost. On the other side of the struggle, and again predictably, there are certain stakeholders that have generally opposed these legislative efforts, and who have advocated the status quo. These groups include plaintiff personal injury attorneys along with other patient advocacy groups. Their side of the argument holds that medical negligence exists; patient injuries and damages are real, and often devastating; and, that the goals of tort law are best met by applying long-standing, tried and true principles. After all, the argument would go, why should the medical industry be given any preferential treatment or "breaks?" Why should a person injured through the negligence of a health care provider be given different (i.e., worse) protections by the judicial system than a person injured, for example, through the negligence of a motorist? Physicians and the health care industry as a group are generally well-off financially and should be heard to fully answer for their acts of negligence. Additionally, nothing is more sacred and important than a 
T. Allan Heller: An Overview of Medical Malpractice Law in the United States Including Legislative and the Health Care Industry's Responses to Increased

human's health and safety when receiving medical attention. Therefore, if a person suffers injury at the hands of a negligent physician or medical facility, those persons and entities should shoulder the full blame. The injured patients should not be made less than whole when a legal claim is rightfully asserted, and, perhaps physicians and health care facilities will learn their lessons and correct poor practices after going through the crucible of the legal system, and for those who don't, seeing what negligent conduct is likely to lead to (malpractice claims and higher insurance premiums, among other negative consequences) they are likely to "up their game," a win for patient safety.

This author does not takes sides in this debate, other than to observe that as in most issues as complicated, nuanced and important as this, all sides have justifiable and credible concerns. The problems are not black and white; the solutions not simple. As imperfect as the United States legal system is, and as unfair as it may seem to some at times, at the end of the day the pulling and tugging; the rigorous, sometimes boisterous case by case nature of our legal system, has at least given all parties forums in which medical malpractice disputes can be resolved. The next part of this paper addresses some of the more important, specific aspects of tort reform; that is, the legislative and judicial responses to the so-called medical malpractice crises.

\subsection{Caps on Damages}

Some health care providers believe that jury awards of non-economic/general damages (e.g. pain and suffering, humiliation) are too often arbitrary, excessive, capricious and punitive in nature. That is, the belief in some physician/health care circles is that the amount of damages sometimes awarded go well beyond reasonable compensation, and that juries sometimes punish physicians because they have deep pockets. Indeed, awards of non-economic damages can in some cases be very significant, amounting to many millions of damages. Of course, very significant damages are often awarded to victorious plaintiffs in non-medical malpractice cases as well, so it is difficult to see where physicians and the health care industry are being singled out by juries for unfair, disparate treatment. Further, in situations where a defendant believes the jury returned an excessively high verdict, defendants have available to them the option to request a remittitur, that is, to file a post-trial motion requesting that the trial court judge reduce the amount of damages. Such motions are authorized under federal rules of civil procedure (FRCP) 59(e) and similar state analogues to the federal rule.

In any case, one significant tort reform measure is that many state legislatures have attempted through legislation to limit, i.e., place "caps" on the amount of noneconomic damages that a jury can award. Those limits vary, for instance: $\$ 250,000$, $\$ 500,000$ or $\$ 1,000,000$. State legislation has most typically sought to place caps on 
non-economic damages. Some states have placed caps on the amount of economic damages that a jury can award. Still fewer states have placed caps on total damages. ${ }^{2}$

Caps on damages have been challenged by plaintiffs and patient advocacy groups on various legal grounds, including that they violate the equal protection clauses in the states' constitution (for good discussion see Parson, 1987). Some state courts have, in fact, found legislative provisions placing caps on damages to be unconstitutional as a matter of their state laws. ${ }^{3}$ Other courts, in some states, have upheld caps in the face of constitutional challenges (Parson, 1987).

\subsection{Limitations on Attorney's Fees}

Under the so-called "American Rule" as a general rule in civil litigation, all sides pay their own attorney fees (and for most but not all out-of-pocket costs, such as filing fees; court reporter fees; expert fees, etc.), win or lose. This is the case in the absence of a statute (known as a "fee-shifting" statute), a contract provision, or some recognized ground in equity. None of these exceptions to the usual American Rule typically apply in medical malpractice cases.

Plaintiffs' counsel in medical malpractice cases (and other personal injury matters) usually only receive an attorney fee if their client either prevails at the trial or achieves a monetary settlement after a lawsuit is filed or at the claims stage, before the actual filing of a lawsuit. This fee is therefore appropriately called a "contingent (on winning money) fee." The percentage of this contingent fee varies, but typically ranges from one-third to forty-percent (sometimes even higher), and hence can be substantial. The medical profession has pointed to excessive fees on the part of plaintiffs' counsel as a significant problem requiring reform, and as contributing to the high costs of delivering health care.

In response to this concern, and as a further tort reform measure, some states have restricted the attorney's contingent fee to no more than a specific percentage of the total award by the jury sometimes decreasing as the size of the award increases (e.g. California Business and Professions Code Sec. 6146). In Washington State, legislation was passed providing that the court shall determine the reasonableness of each party's attorney's fees (see RCWA 7.70.070).

\subsection{Reforms Concerning Expert Testimony}

Practically all medical malpractice cases involve introduction of expert testimony to address issues of both liability (standard or care; breach of standard of care) and, causation. And as discussed earlier in this paper, both sides to the litigation typically will call experts from various disciplines to render opinions on matters pertaining to damages. Members of the health care industry, when lodging criticisms of the 
T. Allan Heller: An Overview of Medical Malpractice Law in the United States Including Legislative and the Health Care Industry's Responses to Increased

legal system, contend that the courts allow too many experts, and that some of the experts allowed to testify lack the proper qualifications to do so.

The trial of most civil cases, even outside the medical malpractice arena, involve substantial expert testimony. This is at least partially the case because under the applicable rules of evidence (both in federal and state courts), and case law interpreting those rules, the threshold requirement for the admissibility of expert testimony is quite low. As a general proposition, the courts will allow expert testimony on a given issue where: the testimony is relevant; the proposed expert testimony will "help" the jury in understanding the evidence or to determine a fact in issue; and, the expert is qualified by experience and/or training to offer the testimony/opinions (Rule 702 of the Federal Rules of Evidence and state court analogues thereto). In complicated cases, such as medical malpractice cases, where complex issues of medicine are at issue, it is easy to see where expert testimony would be helpful to the jury. Indeed, as discussed earlier, expert testimony is both necessary and essential, and without it, neither side could probably put on a case in most instances.

Secondly, the civil rules of procedure, civil rules of evidence, along with related substantive (case) law allows for parties that do not believe: (1) expert testimony is required in the particular case or relating to the particular issue upon which expert testimony is being proffered; or, (2) that the expert is not properly qualified; or, (3) that the proffered opinion(s) lack sufficient acceptance in the scientific community, to take appropriate action to request that the trial judge exclude such testimony. Indeed, trial judges have an important "gatekeeping function" to insure that the proffered "expert" indeed has the requisite expertise to be allowed to render opinions and, importantly, that the opinion testimony has general acceptance in the scientific community. Disputes over whether proffered experts should be allowed to testify, or to render specific opinions, are usually resolved in pretrial motion practice, known commonly as motions in limine. Such motions are usually heard before the trial begins, and outside the presence of the jury.

Despite these existing procedures that can, and in fact are frequently used, to challenge the admissibility of expert testimony, some states nevertheless have passed specific legislation regarding the use of expert testimony in medical malpractice cases. For instance, some states require the experts to be of the same specialty as the physician being sued, and/or that the experts actually be practicing experts.

Further, some states have passed laws providing that the expert must practice or have training in diagnosing or treating the conditions similar to those of the plaintiff and must devote a certain percentage of his or her professional time to clinical practice or teaching in their field of specialty. ${ }^{4}$ 
T. Allan Heller: An Overview of Medical Malpractice Law in the United States Including Legislative and the Health Care Industry's Responses to Increased Claims

\subsection{Pre-Screening of Claims and Alternative Dispute Resolution}

The health care industry also has registered the complaint that there are too many cases that proceed that lack any merit. The author would comment at this point that he practiced insurance defense law for over thirty years, representing scores of defendants that had been sued for a wide array of alleged transgressions. A high percentage of those clients registered the complaint, usually at the outset of the representation, and often as the matter progressed, that they believed the claims against them were meritless.

As is the case concerning experts whose opinion testimony is not really necessary for a fair adjudication of the case, and is also the case concerning excessively high damages awards, the law already contains mechanisms to weed out claims which totally lack merit. One traditional protection against such meritless claims is that the defendant can make a motion before trial to dismiss a case in what is known as a motion for summary judgment, under FRCP 56 and state analogues. The general idea is the court considers all facts and inferences therefrom (based on sworn deposition, declaration testimony and other admissions on file in the court record) in a light most favorable to the plaintiff. When applying those facts to the actual law, if the trial judge hearing the motion concludes no reasonable jury could find in favor of the plaintiff the case should be dismissed, as a trial would in such instance be a wasteful exercise. One admitted drawback of this procedure, however, is that sometimes cases can drag on for many months, or even years, and at substantial expense, before such a motion can be brought and considered by the court, and even if the motion meets with success, the defendant typically cannot recover attorney fees expended in defending. Further, it is true that many trial judges are reluctant, except in the very clearest of cases, to dismiss cases short of a full blown trial on the merits. Theoretically, however, the judge properly performing the gatekeeping function will dismiss the truly meritless lawsuit well before a trial.

Additionally, FRCP 11(b) and (c) provide the federal courts with the authority to sanction "any attorney, law firm, or party" that asserts claims (or defenses) that lack no basis in fact or law. In other words, the court may indeed penalize the lawyers and/or party's that file frivolous claims. The rule further provides that: "Absent exceptional circumstances, a law firm must be held jointly responsible for a violation committed by its partner, associate, or employee." (see, FRCP 11 (c)(1)). Although the trial court is given latitude under the rule to impose various sanctions, the rule in part provides: "if (a sanction) is imposed on motion and warranted for effective deterrence, (the court may issue) an order directing payment to the movant of part or all of the reasonable attorney's fees and other expenses directly resulting from the violation." 
T. Allan Heller: An Overview of Medical Malpractice Law in the United States Including Legislative and the Health Care Industry's Responses to Increased

Claims

In any event, as another element of tort reform, some states have passed legislation requiring the so-called "pre-screening of cases," meaning that medical malpractice cases have to be screened by a panel of experts or a mediator before the case can go to court. Some states require a plaintiff to show at the very outset of the case (i.e., when the case is instituted) that he/she has a qualified medical expert that will support (under oath) the claim being presented. ${ }^{6}$

Various forms of Alternative Dispute Resolution (ADR), including mediation and arbitration, are used with a high degree of frequency in the United States in all types of civil litigation. However, in some states, legislation has been passed permitting health care providers to require that disputes with patients be resolved by arbitration rather than through the courts. In some states, arbitration is voluntary but arbitration clauses are enforced and sometimes the results of arbitration can be introduced in subsequent court trials. In Washington State, the legislature provided for the mandatory mediation of all claims arising from health care injuries. ${ }^{7}$ Other states have initiated so-called Disclosure, Apology and Offering laws. Similar to early arbitration, these initiatives focus on early disclosure of mistakes, apologizing when appropriate, and offering up-front compensation in an effort to avoid costly, time consuming and uncertain litigation. ${ }^{8}$

\subsection{Modifications to Joint and Several Liability Rule}

One of the major tort reform initiatives centers around modifications to the joint and several liability rule that some states have traditionally used as a basis for allocating judgments. The question here focuses on how damages are assessed when there are multiple defendants (which is often the situation in medical malpractice cases) and who pays the damages awarded. To understand the rule, assume a case where there are four defendants: three physicians and a hospital. Following trial, the jury finds one physician $25 \%$ at fault; another physician $25 \%$ at fault; another physician $40 \%$ at fault; and, the hospital where the care was provided only $10 \%$ at fault. Total fault is $100 \%$. These results would be submitted by the jury on what is known as a special verdict form, given to the court clerk by the jury foreperson following jury deliberations.

The law on how liability is assessed, and who can be forced to pay what, varies from state to state. However, to simplify, the traditional rule in tort law has been that any defendant who is found to have been responsible to plaintiff for any percent (even $1 \%$ ) can be forced to pay the entire judgment. The law calls this "joint and several liability." The joint and several liability rule typically comes into play where one or more of the defendants found to be at fault lacks sufficient insurance or assets to satisfy the entire judgment. Under the joint and several rule, the plaintiff can decide to satisfy all of the judgment from one defendant. So in the example above, the hospital would be, under the traditional rule, "jointly and severally liable" and 
at risk for shouldering payment of the entire judgment, even though having been found only $10 \%$ at fault by the jury. (Note: the hospital in this example can attempt to force the other defendant(s) to reimburse it for the defendants' "share" it was forced by the plaintiff to pay.)

The traditional reason underpinning the joint and several rule is that it is more fair to require a negligent party to pay more than its fair share of a judgment than to deny full compensation to the plaintiff. In the medical malpractice setting, and indeed in tort litigation more broadly, defendants have come to see this traditional rule as being unfair and requiring reform. In particular, well-funded (and insured) defendants such as hospitals (or government defendants and large corporations in other civil litigation) argue the rule exposes them to liability well beyond their actual culpability, and therefore punishes them just because they have more insurance or collectible assets.

These concerns have led to modifications of the traditional joint and several liability rule. Some states limit the amount of damages from any defendant to the portion of the injury caused by that defendant (Kansas Statutes Sec. $60-258 \mathrm{a}(\mathrm{d})$ ). This rule is known as "several only liability." Legislation in other states provides that any defendant that is found responsible for $60 \%$ or more of an injury is jointly responsible for the entire amount, but defendants who are found liable for smaller "shares" of an injury are only responsible for their own share of the injury (See 42 Pa. Cons. Stat. Sec. 7012 (b.1)). Other states have enacted other laws that have ameliorated the harshness of the traditional joint and several liability rule. It is worth noting, however, that similar reforms have been made in tort liability not involving health care providers/medical malpractice.

\subsection{Modifications to the Collateral Source Rule}

Tort reform also has focused on modifications to the Collateral Source Rule. Let's assume that the plaintiff proceeds to trial and wins on liability. The plaintiff presents evidence of past medical bills of $\$ 30,000$. The jury awards plaintiff those damages (on the special verdict form), along with other forms of compensation, such as general damages for pain and suffering, that is, non-economic damages. The jury was not informed of this, but as it happened, the plaintiff had various forms of health insurance coverage that already paid for the $\$ 30,000$ in past medical bills. The traditional rule, known as the "Collateral Source Rule," provides that the successful plaintiff can collect the awarded $\$ 30,000$ in medical bills even though those bills already were paid by some third party (e.g., typically a health insurance carrier). ${ }^{9}$ The law typically shields the defendants from introducing evidence of payment of the bills from collateral sources. The health care industry, including insurers, argue the rule is unfair and has contributed to the rising cost of health care, and of malpractice premiums. 
T. Allan Heller: An Overview of Medical Malpractice Law in the United States Including Legislative and the Health Care Industry's Responses to Increased

In response to the complaints, some states have passed legislation in medical malpractice cases that has modified the Collateral Source Rule. In particular, some state laws require medical malpractice awards to be reduced by collateral payments, and in other states the jury is informed of the collateral payments and can take them into account in deciding upon damages. ${ }^{10}$ Other states have modified the traditional rule in yet other ways, to again attempt to limit the harshness of the hard and fast rule.

\subsection{Modifications to Statutes of Limitation}

Statutes of limitation govern the length of time an injured person has to commence a legal proceeding against a defendant. Health care providers have argued some of the statutes are too long. These statutes are designed to insure that claims are not allowed to be asserted so long after the triggering event that evidence can no longer be found to defend the claim, i.e., to guard against "stale" claims. There are competing interests in cases involving medical injury. On the patients' side, sometimes injuries sustained as a consequence of poor/negligent care cannot be ascertained for many years after the care has been provided. Too short a statute of limitations can therefore in some instances be unfair to the injured patient. On the other side of the equation, a lack of clarity about when a claim might be asserted leads to uncertainty, sometimes lost evidence (including witnesses or documents), and therefore can be unfair to the medical profession. This can lead to increased medical malpractice premiums along with other undesirable consequences.

In response to these concerns, many attempts at tort reform have centered on the issue of the applicable statute of limitations in medical malpractice cases (Stark, 2016). Some states have shortened the statutory period. Other states have enacted legislation that starts the "time clock running" from the time an injury occurred, irrespective of whether it is apparent from that point in time or not, while others don't impose a time limit until the injured person had a reasonable period to discover the injury. This later concept is known as a "discovery rule" and various states across the United States have written laws that limit the time a plaintiff has to initiate a claim after discovering the injury and/or the negligence that caused it.

\subsection{Patient Compensation Funds and Pre-Suit Notices of Claims}

Some states have created patient compensation funds. The idea is to place some upper limit or cap on the amount of damages that a medical provider has to pay the injured patient, while at the same time insuring that the patient can be made whole by receiving additional funds from a state sponsored patient compensation fund. 
Some states have passed legislation requiring a plaintiff, as a pre-condition of later filing a lawsuit, to first provide written notice to the potential defendant (health care provider) of the claim. The notice would have to include information such as the particular negligence asserted, the damages being claimed and like information. A typical time limit would be at least 30,60 or 90 days before filing suit. The idea here is to give the parties a chance to settle their dispute without the need for a timeconsuming and costly lawsuit. Some of these laws have been struck down by the courts as being in violation of state constitutional law. ${ }^{11}$

\subsection{Other Proposed Tort Reform Measure - Time for a No Fault Compensation Fund in Medical Malpractice Cases?}

Some scholars have suggested that the state-by-state approach to resolving medical negligence claims in the traditional tort system is far too complicated, time consuming and expensive and therefore should be replaced entirely with a no-fault system that would offer certain compensation for injured patients (Flis, 2016). For instance, states all have industrial insurance laws that protect workers injured during the course and scope of their employment. Although these schemes vary from state to state, the common denominator underlying each is that when a worker suffers injury, that worker will recover defined benefits under the state's compensation laws, irrespective of whether anyone (i.e., the injured worker, or the employer, or a co-worker) was at fault in causing the injury. Defined benefits typically include payment of medical bills, loss of earnings, and a lump sum payment for any permanent, partial disability. These schemes are funded by ongoing contributions made by employees and employers.

From the author's experience and knowledge, it is difficult to see this proposal garnering the necessary support to ever become reality in the United States. Such an approach was attempted, for example, in the asbestos litigation, the longest running mass tort ever. As is true with health care providers, asbestos manufacturers and their insurers decried the handling of asbestos claims in the traditional tort system and for many years lobbied the United States Congress to establish an Asbestos Compensation Fund that would provide certain defined compensation to victims of asbestos-related disease. In fact, huge amounts of money were spent in transactional costs in these lawsuits (i.e., expert fees, attorney fees, depositions, records gathering, pre-trial and trial litigation, etc.) that could have been used to simply compensate the victims. If ever there had been a substantive area of the law where it would have made sense to provide injury victims with certain and defined compensation outside the traditional tort system, the asbestos arena was it. However, the plaintiffs' trial lawyers and other groups fought this proposal and in the end the United States Congress narrowly voted down the proposal, and so the tort litigation continues, for better or worse (Miller, 2006). 
T. Allan Heller: An Overview of Medical Malpractice Law in the United States Including Legislative and the Health Care Industry's Responses to Increased

Claims

\subsection{Has Tort Reform Made a Difference?}

There is substantial debate over the extent to which tort reform measures have reduced medical malpractice costs and otherwise helped to alleviate the rising costs associated with the delivery of medical care (Belk, 2014). It would appear that some studies have concluded that in states where caps on damages are in place, medical malpractice premiums have in fact decreased. It has been stated that the cap on damages has been the most significant and effective tort reform measure in helping to reduce malpractice premiums. However, others have concluded that caps on damages might have no or little impact on malpractice premiums (Zeiler \& Hardcastle, 2012). On the other hand, it would appear there is more debate over whether tort reform measures of all types have actually decreased physicians' practice of engaging in "defensive medicine" to help avoid malpractice claims, and whether these measures otherwise have assisted in lowering the overall cost of delivering health care in the United States and making health care more readily available (Zeiler \& Hardcastle, 2012).

Reforms, especially caps on non-economic damages, seem to have worked in states including California, Colorado, Kansas, and Texas. Litigation in those states has decreased and malpractice premiums remain relatively low. Litigation is still very frequent and malpractice premiums are high in New York City, Washington D.C., New Jersey and Delaware, all of which have seen less meaningful tort reform. There is evidence that medical malpractice premium rates in average have decreased since 2008. However, some physicians practicing in high-risk specialties such as OBGYN's and surgeons pay annual premiums of $\$ 100,000$ or more (Lowes, 2016).

Pre-law suit screening requirements, where instituted, also seem to have helped to limit litigation. Many studies have been undertaken which have tried to measure the impact of tort reform efforts on the costs of medical care and of costs associated with medical malpractice claims. However, there are so many confounding variables involved in these analyses that hard and fast quantifications have proved difficult. For example, there are some areas of the United States that are simply less litigious overall than other areas. Minnesota is one such state. Minnesota physicians pay some of the lowest malpractice premiums in the United States. There are fewer claims made against health care providers in that state. It seems doubtful that physicians in Minnesota are better trained and more careful than those in New York and Delaware where claims are typically higher (n.p., 2015). The conclusion, seemingly, is that the overall culture in any given state plays a role. 
T. Allan Heller: An Overview of Medical Malpractice Law in the United States Including Legislative and the Health Care Industry's Responses to Increased Claims

\section{Responses by the Health Care Industry Outside the Legislative and Judicial Context}

We have now discussed in some detail legislative and judicial responses to the problems of the high incidence of medical malpractice claims and the attending negative consequences of that high volume of claims. But how has the health care industry itself responded to the problem, aside from pushing its legislative and judicial agendas? The balance of this paper addresses that question.

Recall that at the outset of the paper, the point was made that the tort system itself is designed to achieve multiple policy objectives, which often come into conflict with one another, and the ongoing dilemma is striking an appropriate balance. To be sure, the law wants to compensate deserving victims of injury and to provide them appropriate redress. The law also wants to foster safe practices and to deter wrongdoing. At the same time the law wants to avoid policy that unduly stifles economic development and that places undue stress on commerce. Having available and affordable insurance also is an important policy objective.

\subsection{The Traditional Model: An Overview - Solo or Small Group Physician Practices}

Traditionally, many physicians practiced alone or in very small groups. Each doctor or small groups of doctors purchased their own medical malpractice insurance. These individual physicians also had to take it upon themselves to keep abreast of developments in medicine, such as best practices and standards of care. For some of the reasons discussed earlier, from time to time; from place to place; and, from specialty practice to specialty practice, malpractice insurance became very expensive to purchase, and sometimes not attainable at all. Physicians chose not to practice in geographical locations where they were most likely to have claims asserted against them. These consequences were and are undesirable not only to those in the medical field, but to the general public.

Furthermore, traditionally many physicians merely had privileges to practice at their local hospitals and were not considered "employees" but rather, as "independent contractors" and therefore may not have been covered by the hospitals' malpractice coverage, but rather by his/her own malpractice insurance. Traditionally hospitals and staff physicians were separate legal entities and different legal theories applied to each when it came to assessing their respective liabilities to a patient. Accordingly, a hospital might not have legal liability for a physician practicing there, since the hospital was not actually providing the treatment. Sometimes, however, special rules under the law of Principal and Agency (such as "Apparent Agency") were used by plaintiffs' attorneys and the courts to circumvent this problem. 
T. Allan Heller: An Overview of Medical Malpractice Law in the United States Including Legislative and the Health Care Industry's Responses to Increased

Therefore, plaintiffs' attorneys that represent injured patients have always had to concern themselves about suing the "correct" legal entities. If, for example, they sued only the hospital where the care was provided, the hospital was likely to assert as a defense that the physician that performed the allegedly poor medical services was not an "employee" but rather only an "independent contractor" and therefore assert that the hospital itself was not legally responsible for that physician's conduct. Out of (legitimate) fear of attorney legal malpractice, the reasonably prudent plaintiff medical malpractice lawyer would typically join in the lawsuit both the hospital and all physicians that provided care to the injured patient/plaintiff. Sometimes the defendants would end up "pointing fingers" at each at the trial, a tactic that often plays right into the hands of the plaintiff, as the jury often then comes to the conclusion that one or all of the defendants "must be at fault" given all of the finger pointing and infighting among defendants. These considerations added litigation expense to both the plaintiffs and defendants.

The traditional insurance models also were costly to the defendants, both the individual physicians and the health care facilities, both of whom had to purchase insurance at increasing costs to both, especially during the times of "crisis" as discussed previously.

\subsection{The Move Toward Consolidation of the Health Care Industry}

While the various legislative tort reform measures discussed earlier apparently have met with some success (but difficult to quantify, as mentioned earlier), the continued uncertainty regarding the availability of insurance and, when available, its cost, coupled with the desires to both improve the quality of the delivery of health care and to control costs, has led to certain systemic changes or trends in the health care system and the methods used to insure both individual physicians and medical facilities. The author practiced law in Washington State for many years (and received health care there) and hence some of the discussion here will focus on developments in Washington State, in particular, although these comments hold true as well for many places in the United States.

Over the past several decades, the trend has been toward the formation of larger and larger healthcare organizations and for hospitals to directly employ significantly more physicians (Karash, 2013). Along with the reasons discussed previously in this paper, these developments have been driven by the need to consolidate in order to have stronger bargaining position when negotiating reimbursement rates with first party health insurers. Indeed, some of the literature suggests this has been a primary driver of the trend toward greater consolidation in the industry. Furthermore, an increasing number of hospitals are owned by, and physicians are employed by, these large healthcare organizations. In Washington State, by way of 
example, there are very large institutions such as Virginia Mason, MultiCare, and the University of Washington, which directly employ very large numbers of physicians and other employees. ${ }^{12}$ Although a complete discussion is beyond the scope of this paper, apparently there are significant questions regarding whether this consolidation has actually led to improved quality of care and reduced costs. ${ }^{13}$

\subsection{Alternatives to Traditional Insurance Models - Self Insurance}

Following the first national spike in medical malpractice claims in the 1970's, many physicians could not find malpractice insurance or, if they could, the premiums were very high. As previously discussed, this led in turn to serious, adverse public health concerns, as physicians refused to practice in certain parts of the country, or to practice certain high risk specialties, thus resulting in shortages in necessary medical care to persons living in those areas of the country.

In response, and in addition to the trend in consolidation, both physicians and hospitals started to form their own risk pools or mutual insurance companies. In Washington State, for example, nearly 100 physician-owned insurance companies started up during this period to fill the void left by traditional carriers that left the marketplace. In 1982, physicians in Washington State, along with the Washington State Medical Association, banded together to form what is now called Physicians Insurance (a mutual company), which insurers about $80 \%$ of Washington physicians (Stark, 2015). Physician-owned companies insure more than half of United States physicians who buy their own insurance.

An overwhelming majority of hospitals now use the self-insurance model to provide liability coverage for their employed physicians. With many physicians now being directly employed by hospitals, they are now insured by the hospital (or other large healthcare facility) where they work. This model, among other benefits, at least theoretically should enable hospitals and health care facilities to promote uniformity in physician practices.

\subsection{Group Captives as Modern Insurance Alternative}

According to a recent study in the New England Journal of Medicine, only 1\% of physicians account for almost one-third of paid medical malpractice claims. This study also found that just $6 \%$ of physicians had a paid malpractice claim during the study's time period, which was 2005 - 2014 (Dethlefs, 2016). Although those percentages overall are low, both physicians and other health care providers, such as hospitals, must insure themselves against the risk of a costly malpractice claim. Economic pressures have forced the healthcare industry to constantly search out new options to insure against those risks. 
One such option the healthcare industry has turned to is a group captive (Dethlefs, 2016). In essence, a captive is an insurance company that is wholly owned and controlled by its insureds. Its primary purpose is to insure the risks of its owners, who also benefit from the captive insurer's underwriting profits. In a group captive, hospitals and other healthcare providers agree to share each other's risk of loss from professional liability and other exposures. This element of shared risk results in a requirement of greater accountability for each member. Group captive members can participate in collective and cooperative efforts, sharing best practices and identifying emerging trends and issues, in order to have a learning organization. Members of the captive can rely on one another to offer insights in order to improve patient safety and prevent medical errors from recurring. A further benefit of a captive is that as a consequence of these cooperative efforts at minimizing risks through the promotion of best practices and patient safety, the captive ideally will generate profits from favorable operating results.

Captives also allow the owners to draft custom-tailored insurance policies to fit their exact needs. This allows the owners to minimize, if not totally eliminate, exclusions found in the more typical insurance policies. Captives also allow owners to assign their own defense counsel when a claim is asserted, instead of having to use whatever legal counsel is assigned by the insurance company (Adkisson, 2013). ${ }^{14}$ Furthermore, the owner can administer claims on its own terms, instead of the terms dictated by the traditional insurance carrier. Finally, a prime purpose of the captive is to save money on the cost of insurance. By underwriting the insurance needs of the business, the captive can capture and retain the underwriting profits that would ordinarily be lost to the commercial carrier.

\section{Conclusion}

The delivery of quality, affordable, and universal health care is one of the most important public policy issues the United States (and obviously all countries) faces. Despite the best efforts of the medical profession, medical errors will always occur to some extent. As this paper has overviewed, over the last $40-50$ years stakeholders have attempted both legislatively and non-legislatively to arrive at solutions to deal with the adverse consequences of the high volume of medical malpractice claims. There is considerable debate over the success of the efforts at tort reform.

The health care industry has undergone fundamental restructuring in the way medical care is delivered. Many physicians now practice in group settings. Many physicians now work as direct employees of hospitals. An increasing number of physicians and health care facilities are self-insured under various models, including group captives. Important objectives of these developments include sharing of best practices; creation of teaching organizations; uniformity of practice; 
and, hopefully, better overall patient safety (i.e., less medical negligence with fewer malpractice claims).

Returning once again to the objectives of tort law generally, the optimist would hope that silver linings from the earlier malpractice crises have been more diverse, healthier forms of delivery of medical services and insurance, which might benefit both patients and the medical providers that service them. Should that turn out to be the case, perhaps the natural consequences of the tort system might in the long run benefit patient safety in a way the tort reform measures discussed earlier in this paper could not. Some of the recent literature, however, suggests that the trend toward consolidation has meant a lack of competition, and therefore has contributed to both increased costs of medical care and without the increases in patient care and quality hoped for.

\section{Acknowledgment:}

The author gratefully acknowledges Paul Gordon Heller for his research and editing assistance in the preparation of this paper. Paul Gordon Heller graduated from Washington State University with majors in International Business and German.

\section{Notes}

${ }^{1}$ The general rule is that expert medical testimony is necessary to establish the relevant standard of care and causation in a negligence action against a health care provider. See, e.g., Winkler v. Giddings, 146 Wash. App. 387, 190 P.3d 117 (Div. 3 2008).

${ }^{2}$ For a good, recent survey of caps by state, see Morgenstern, 2005. The author in this article states that the average cap per state was $\$ 626,650$. As of the writing of that article, the author wrote that 31 states had damage caps. The lowest cap was $\$ 250,000$. The types of caps varied significantly. For instance, Virginia's cap is set to increase $\$ 50,000$ annually until it hits $\$ 3,000,000$ in 2031 . In the State of Indiana, any damages in excess of $\$ 250,000$ for an individual health care provider is covered by the state. New Mexico's cap does not apply to punitive damages.

${ }^{3}$ Missouri, Alabama, New Hampshire, Oregon, Washington, Illinois, and Georgia have all struck down legislation that attempted to place caps on damages, finding such legislation unconstitutional under those states' constitutions. (Lowes, 2012).

${ }^{4}$ For example, West Virginia passed legislation requiring that the expert witness must practice or have training in diagnosing or treating conditions similar to those of the patient and must devote a certain percentage of his or her time to clinical practice or teaching in their field or specialty (Virginia Code Sec. 55.7B.7).

${ }^{5}$ See, FRCP 11(4). State courts have similar rules and therefore, in appropriate cases an attorney filing a totally frivolous medical malpractice action faces the prospect of a possible motion for sanctions. Some state courts have other statutes that might also allow trial courts to order sanctions for the bad faith assertions of claims or defenses. See, e.g., Washington State provision RCWA 4.84.185 entitled, "Prevailing party to receive expenses for opposing frivolous action or defenses." This statutory provision provides, among other things, that the trial judge may require a party to pay the prevailing party's reasonable expenses and attorney fees for asserting a frivolous claim. 
T. Allan Heller: An Overview of Medical Malpractice Law in the United States Including Legislative and the Health Care Industry's Responses to Increased

Claims

${ }^{6}$ In Washington State, the legislature enacted a requirement that in the filing of a medical malpractice action and related pleadings the responsible attorney must file an accompanying certificate stating that there is a good faith basis in law and in fact for the claims or defenses being asserted RCWA 7.70.160.

${ }^{7}$ RCWA 7.70.100. In Washington, after unsuccessful mediation, the parties retain the right to a trial by jury. RCWA 7.70.120.

${ }^{8}$ See, e.g., RCWA 5.64.010(3). The author would note that he defended many civil cases where it became apparent that had the defendant either merely apologized for wrongful behavior or had the insurance carrier for the defendant paid the plaintiff's medical bills (with no other compensation) following a tortious event, the plaintiff would not have filed a lawsuit.

${ }^{9}$ It should be pointed out, however, that the entity that originally paid for the plaintiff's medical treatment/bills, i.e., an insurance carrier, will almost always have a contractual right, known as a subrogated interest or lien, to recover those payments out of any judgment or settlement, although often that carrier will agree to reduce the amount of its subrogated interest. The plaintiff's attorney typically will also be entitled to an attorney fee for assisting the carrier in helping to recoup on its lien. Given the fact the lienholder has to be re-paid out of a judgment or settlement, it is not accurate to say that under the traditional collateral source rule the plaintiff is completely "double-dipping."

${ }^{10}$ In Washington State, for example, the collateral source rule was restricted to permit introduction of evidence that the plaintiff received compensation from insurance paid for by the plaintiff or the plaintiff's employer (see RCWA 7.70.080). For other similar efforts in other states see also Florida Statutes Sec. 768.,76 and Tennessee Code Sec. 29-26-119.

${ }^{11}$ In Washington State, for example, the requirement in RCWA 7.70.100(1) that medical malpractice plaintiffs provide defendants with 90 days written notice of claim prior to filing suit was found to be unconstitutional in Waples v. Yi, 169 Wash. 2d 152, 234 P.3d 187 (2010), as applied to defendants other than the State of Washington (i.e., private parties) because of its failure to honor the separation of powers required by the state constitution. On the other hand, the Washington State Supreme Court found the statute constitutional regarding governmental entities under the doctrine of sovereign immunity. McDevitt v. Harborview Medical Center, 291 P.3d 876 (2011).

${ }^{12}$ For a good discussion see article, Gaynor \& Town, 2012. The authors state, regarding consolidation: "Increasing numbers of physicians are working as hospital employees and increasing numbers of physician practices are owned by hospitals. The number of physicians working as employees grew from around 31\% in 1996-97 to 36\% in 2004-05 Another survey found that that the percentage of primary care physicians employed by hospitals rose from under $20 \%$ in 2000 to over $30 \%$ in 2008 and the percentage of specialists employed by hospitals rose from just over $5 \%$ to $15 \%$. The percentage of physician practices owned by hospitals rose from around $20 \%$ in 2002 to over $50 \%$ by 2008."

13 For example, Gaynor \& Town, 2012 state: "[SUMMARY OF KEY FINDINGS] Physician-hospital consolidation has not led to either improved quality or reduced costs. Studies find that consolidation was primarily for the purpose of enhanced bargaining power with payers, and hence did not lead to true integration. Consolidation without integration does not lead to enhanced performance." See also Evans Cuellar \& Gertler, 2015 - the authors conclude, in part, that hospital consolidation has resulted in more negatives than positives for consumers so far. They also state the evidence suggests that hospital system formation has primarily served to increase market power, not improve patient care quality or hospital efficiency, at least in the short run. 
14 Additionally, this form of self-insurance allows the owners more self-direction in determining what cases to settle and which to litigate. Under more traditional insurance models, these decisions were often left to the insurance claims adjustors, who sometimes made decisions the physicians did not like.

\section{References}

Adkisson, J. (2013) Ten Favorite Things About Captive Insurance Companies, Forbes. Forbes Magazine, (August 10, 2013), available at: http://www.forbes.com/sites/jayadkisson/2013/08/10/ten-good-non-tax-things-aboutcaptive-insurance-companies/\#6eac4596c599 (July 9, 2017).

American Hospital Association (2016) Fast Facts on US Hospitals."Ed. Ahahospitals. Health Forum LLC (December 1, 2016), available at: http://www.aha.org/research/rc/statstudies/fast-facts.shtml (July 9, 2017).

Bal, B. S. (2009) An Introduction to Medical Malpractice in the United States, Clinical Orthopaedics and Related Research, 467(2), pp. 339-347, doi: 10.1007/s11999-0080636-2.

Belk, D. (2014) True Cost of Health-Care, available at: http://truecostofhealthcare.org/ (July 9, 2017).

Dethlefs, E.W. (2016) Opinion: Captive Insurance Models Foster High-value Care, Managed Healthcare Executive. Modern Medicine Network, available at: $\mathrm{http}: / /$ managedhealthcareexecutive.modernmedicine.com/managed-healthcareexecutive/news/opinion-captive-insurance-models-foster-high-value-care?page $=0 \% 2 \mathrm{C} 0$ (June 20, 2017).

Evans Cuellar, A. \& Gertler, P. J. (2005) Market Watch, How the Expansion of Hospital Systems Has Affected Consumers, Health Affairs, 24(1), pp. 213-219, doi: 10.1377/hlthaff.24.1.213.

Flis, V. (2016) No Fault Compensation for Medical Injuries, Medicine, Law and Society, 9(2), pp. 73-84.

Gaynor, M. (2012) The Impact of Hospital Consolidation - Update. Technical Report, available at: http://archwayhealth.com/wpcontent/uploads/2016/10/Gaynor_Town_rwjf_update.pdf (September 12, 2017), doi: 10.13140/RG.2.1.4294.0882.

Karash, J. A. (2013) Liability Coverage at a Crossroads, H\&HN. Hospitals and Health Networks, (February 1, 2013), available at: http://www.hhnmag.com/articles/6074liability-coverage-at-a-crossroads (July, 5 2017).

Kraljić, S. (2017) Health Literacy as a Key Element for Safety of Patient and Health Professionals, In: Kraljić, S., Reberšek Gorišek, J. \& Rijavec, V. (eds.) Varnost pacienta in zdravstvenih delavcev: (konferenčni zbornik), 26. posvet Medicina, pravo in družba, 23.-24. marec 2017, Maribor (Maribor: Univerzitetna založba Univerze), pp. 127-139.

Lowes, R. (2012) Missouri Supreme Court Strikes Down Malpractice Cap, Medscape, available at: http://www.medscape.com/viewarticle/768520 (September 25, 2017).

Lowes, R. (2016) Malpractice Premiums Trial Inflation for Some Physicians, Medscape, available at: http://www.medscape.com/viewarticle/873422 (September 13, 2017). 
T. Allan Heller: An Overview of Medical Malpractice Law in the United States Including Legislative and the Health Care Industry's Responses to Increased Claims

Mello, M. M. Studdert, D. M., DesRoches, C. M., Peugh, J., Zapert, K., Brennan, T. A., Sage, W. M. (2005) Effects of a Malpractice Crisis on Specialist Supply and Patient Access to Care, Annals of Surgery, 242(5), pp. 621-628.

Miller, J. P. (2006) Asbestos Fund Falls Short, Chicago Tribune, (February 15, 2006), available at: http://articles.chicagotribune.com/2006-0215/business/0602150227_1_billion-asbestos-compeensation-fund-senate-votes-usg (July 9, 2017).

Morgenstern, M. (2005) Medical Malpractice Damages Caps: A State By State Comparison, available at: https://www.theexpertinstitute.com/medical-malpractice-damages-caps-astate-by-state-comparison/ (October 2, 2017).

n.p. (2015) Medical Malpractice Payouts Continue to Climb in U.S, Insurance Journal, (June 15, 2015), available at: http://www.insurancejournal.com/magazines/features/2015/06/15/371045.htm (7.9.2017).

Parson, J. A. (1987) Medical Malpractice Damage Caps: Navigating the Safe Harbors, Washington University Law Review, 65(3), pp. 565-587, available at: http://openscholarship.wustl.edu/law_lawreview/vol65/iss3/3 (September 29, 2017).

Prosser, W. L., Keeton, W. P., Dobbs, D. B., Keeton, R.E. \& Owen, D. G. (eds.) (1984) Prosser and Keeton on the Law of Torts, $5^{\text {th }}$ ed. (St. Paul, Minn.: West Publishing Co.).

Stark, R. (2016) The cost of medical malpractice lawsuits in Washington State - Lessons from Texas Reform, Washington Policy Center, (April 11, 2016), available at: https://www.washingtonpolicy.org/publications/detail/the-cost-of-medical-malpracticelawsuits-in-washington-state-lessons-from-texas-reform (October 18, 2017).

Statista (2015) All Products Require an Annual Contract. Prices Do Not Include Sales Tax (New York Residents Only), Statista. "Doctor Visits per Capita by Country 2015 Statistic." Statista. Statista, 25 Oct. 2015. available at: https://www.statista.com/statistics/236589/number-of-doctor-visits-per-capita-bycountry/ (July 9, 2017).

The Council for State Governments (2003) Medical Malpractice Crises, Trends Alert, available at: http://www.csg.org/knowledgecenter/docs/TA0304MedMal.pdf (October 1, 2017).

Unver, Y. (2016) The legal nature of doctor patient relationship in Turkish Medical Law, Medicine, Law and Society, 9(2), pp. 59-71.

U.S. Congress, Office of Technology Assessment (1994) Defensive Medicine and Medical Malpractice, OTA-H--6O2 (Washington, DC: U.S. Government Printing Office).

US Dept of Health \& Human Services (2014) NPDB Research Statistics, The NPDB - NPDB Statistics, (National Practitioner Data Bank), available at: https://www.npdb.hrsa.gov/resources/npdbstats/npdbStatistics.jsp (July 9, 2017)

Young, A., Humayun, C., Xiaomei, P., Arnhart, K. \& Dugan, M. (2014) A Census of Actively Licensed Physicians in the United States, 2014, Journal of Medical Regulation, 101(2), pp: 8-23.

Zeiler, K. \& Hardcastle, L. E. (2012) Do Damages Caps Reduce Medical Malpractice Insurance Premiums?: A Systematic Review of Estimates and the Methods Used to Produce Them, Georgetown Public Law and Legal Theory Research Paper No. 12-186 \& Georgetown Business, Economics and Regulatory Law Research Paper No. 12-042, available

http://scholarship.law.georgetown.edu/cgi/viewcontent.cgi?article=2140\&context=facp ub (September 12, 2017). 